\title{
Peran Balai Harta Peninggalan Dalam Peralihan Hak Tanah Bagi Keturunan Arab Di Yogyakarta
}

\author{
Wahyu Hadis \\ Magister Kenotariatan Universitas Islam Indonesia \\ Jln. Cik Di Tiro No. 1, Yogyakarta, 55223 \\ wahyu.hadis21@gmail.com
}

\begin{abstract}
Circular Letter of the Ministry of Domestic Affairs of the Directorate General of Agrarian Number Dpt/12/63/12/69, dated December 20, 1969, stated that the certificate of inheritence can be made by a Notary, Head of District, and also the Heritage Centre. Departing from this, this study aims to analyze and understand the role of the Heritage Center in the transfer of inheritance rights to land of Indonesian citizens of Arab descent in the Special Region of Yogyakarta and understand the legal consequences if it is known that the inheritance certificate of Arab descent was issued by the Village Government or Public Notary on the transfer of Land rights. The results of the study show that in the case of the certificate of inheritance of an Indonesian citizen of Arab descent is an absolute product and the full authority possessed by the Heritage Centre, there are two legal consequences if it is known that the certificate of inheritance of Far Eastern Indonesian citizens is made by a Notary or Village Government in Submission of Transition Inheritance rights at the National Land Agency are null and void and can be canceled if there is a transfer.
\end{abstract}

Keywords: Heritage centre; Arab descent; certificate of inheritence

\begin{abstract}
Abstrak
Surat Edaran Departemen Dalam Negeri Direktorat Jendral Agraria Nomor Dpt/12/63/12/69, tanggal 20 Desember 1969, menyatakan bahwa surat keterangan ahli waris dapat dibuat oleh Notaris, Camat, dan juga Balai Harta Peninggalan. Berangkat dari hal tersebut, penelitian ini bertujuan menganalisis dan memahami peran Balai Harta Peninggalan dalam peralihan Hak Waris Atas Tanah Pada Warga Negara Indonesia Keturunan Arab di Daerah Istimewa Yogyakarta dan memahami akibat hukum apabila diketahui Surat Keterangan Waris keturunan Arab dikeluarkan oleh Pemerintah Desa atau Notaris terhadap peralihan Hak Atas Tanah. Hasil penelitian menunjukkan bahwa dalam hal Akta Keterangan Waris Warga Negara Indonesia Keturunan Arab merupakan mutlak produk dan kewenangan sepenuhnya yang dimiliki oleh Balai Harta Peninggalan. Ada dua akibat hukum apabila diketahui surat keterangan waris WNI keturunan Timur asing dibuat oleh Notaris atau Pemerintahan Desa dalam Pengajuan Peralihan Hak Waris di Badan Pertanahan Nasional yaitu batal demi hukum dan dapat dibatalkan apabila telah terjadinya peralihan.
\end{abstract}

Kata-kata Kunci: Balai harta peninggalan; keturunan Arab; surat keterangan waris 


\section{Pendahuluan}

Indonesia merupakah negara kepulauan yang terdiri dari ribuan pulau yang berjajar di seluruh wilayahnya dan menjadikan kebudayaan dan suku maupun etnik di Indonesia sangat beragam. Letak geografis Indonesia yang sangat strategis menjadikan Indonesia sebagai pusat lalu lintas perdagangan dan peradaban dunia, sehingga banyak pendatang dari luar negeri berdatangan dan menetap di Indonesia. Pendatang dari Arab menjadi salah satu dari sekian banyak etnik yang datang dan menetap di Indonesia. Kedatangan mereka tidak hanya sekedar untuk singgah, bahkan mereka juga menetap dan menjadi kewarganegaraan Indonesia.

Warga keturunan Arab yang menetap di Indonesia menjadi Warga Negara Indonesia melahirkan banyak keturunan yang berstatus Warga Negara Indonesia (WNI), dari keturunan tersebut tidak menutup kemungkinan mengenai peralihan waris, khususnya waris mengenai tanah di Indonesia.

Perolehan kekuatan pembuktian tanah dari hasil pewarisan, maka surat keterangan waris sangat diperlukan di samping sebagai dasar untuk pendaftaran tanahnya. Namun, sampai saat ini untuk memperoleh surat keterangan waris, hukum yang berlaku bagi WNI masih berbeda-beda. ${ }^{1}$ Menurut Peraturan Pemerintah Nomor 10 Tahun 1961 tentang Pendaftaran Tanah dalam Pasal 25, Surat Keterangan Waris itu merupakan suatu keharusan. Hanya saja, pejabat yang berwenang untuk membuat Surat Keterangan Waris itu belum ditemukan. ${ }^{2}$

Dari Surat Edaran Departemen Dalam Negeri Direktorat Jendral Agraria di bawah Nomor DPT/12/63/12/69, tanggal 20 Desember 1969, untuk Warga Negara Indonesia (WNI) ditentukan golongan yang hendak membuat Surat Keterangan Waris ada empat kemungkinan yaitu: ${ }^{3}$

1. Golongan Keturunan Barat (Eropa) dibuat oleh Notaris;

2. Golongan Penduduk Asli, dibuat oleh Ahli waris, yang suratnya disaksikan oleh Lurah dan diketahui oleh Camat;

3. Golongan Penduduk Keturunan Tionghoa juga dibuat oleh Notaris;

4. Sedangkan golongan keturunan Timur Asing lainya dibuat oleh Balai Harta Peninggalan.

${ }^{1}$ Ardian Sutedi, Peralihan Hak Atas Tanah dan Pendaftarannya, Sinar Grafika, Jakarta, 2010, hlm. 102.

2 Ibid.

${ }^{3}$ Surat Edaran Departemen Dalam Negeri Direktorat Jendral Agraria di bawah nomor DPT/12/63/12/69, tanggal 20 Desember 1969. 
Kantor Pertanahan, sebagai institusi yang mengurus pendaftaran tanah akibat peralihan tanah karena terjadi pewarisan, selalu meminta bukti surat keterangan waris dari ahli waris yang harus juga dilengkapi dengan surat kematian untuk menentukan bahwa ahli waris yang mendapat hak atas tanah tersebut adalah benar ahli waris dari pewaris yang bersangkutan. Hal ini diatur dalam Pasal 42 ayat (1) Peraturan Pemerintah Nomor 24 Tahun 1997 tentang Pendaftaran Tanah jo. Pasal 111 ayat (1) huruf c angka 4 Peraturan Menteri Negara Agraria/Kepala Badan Pertanahan Nasional Nomor 3 Tahun 1997 tentang Pelaksanaan Peraturan Pemerintah Nomor 24 Tahun 24 Tahun 1997 tentang Pendaftaran Tanah dan Surat Edaran Departemen Dalam Negeri Direktorat Jenderal Agraria tanggal 20 Desember 1969 Nomor Dpt/12/63/12/69 tentang Surat Keterangan Warisan dan Pembuktian Kewarganegaraan ${ }^{4}$.

Berdasarkan pada ketentuan di atas, nyatanya terdapat banyak institusi yang dapat membuat surat keterangan ahli waris. Seiring berjalanya waktu, masyarakat umum masih sering menanyakan institusi manakah yang tepat untuk membuat surat keterangan ahli waris, baik Warga Negara Indonesia yang merupakan keturunan maupun asli Indonesia atau pribumi.

Surat Edaran Departemen Dalam Negeri Direktorat Jendral Agraria di bawah Nomor DPT/12/63/12/69, tanggal 20 Desember 1969, menyatakan bahwa surat keterangan ahli waris dapat dibuat oleh Notaris, Camat dan Balai Harta Peninggalan. Keturunan Arab yang sudah menjadi Warga Negara Indonesia merupakan golongan keturunan Timur Asing lainya, yang mana menurut peraturan perundang-undangan yang berlaku, yang berwenang membuatkan Surat Keterangan Waris bagi keturunan Timur Asing lainya adalah Balai Harta Peninggalan.

Akan tetapi, Notaris di Indonesia, khususnya yang berada di wilayah kerja Daerah Istimewa Yogyakarta, justru masih sedikit yang mengetahui bahwa Surat Keterangan Waris keturunan Timur Asing seharusnya dibuat oleh Balai Harta Peninggalan. Notaris masih berpendapat bahwa Surat Keturunan Timur Asing

${ }^{4}$ Habib Adjie, Pembuktian Sebagai Abli Waris Dengan Akta Notaris (Dalam Bentuk Akta Keterangan Waris), Mandar Maju, Bandung, 2008, hlm. 7. 
dapat dibuat oleh Notaris itu sendiri, dengan mengesampingkan kewenangan Balai Harta Peninggalan.

Balai Harta Peninggalan pada mulanya hanya didirikan untuk memenuhi kebutuhan Kompeni Belanda (Vereenigde Oostindische Compagnie, (VOC)) yang kemudian semakin berkembang dan meluas mencakup mereka yang termasuk golongan Eropa, Cina, dan Timur Asing lainya. Bahkan dengan perkembangan hukum di Indonesia dan semakin pesatnya kemajuan dalam bidang ekonomi dan perdagangan, telah menarik banyak orang-orang dari golongan pribumi menundukkan dari secara sukarela kepada Hukum Perdata Barat dan melaksanakan hubungan-hubungan hukum yang merupakan materi yang diatur dalam Kitab Undang-Undang Hukum Perdata (KUHPer), Namun demikian, hingga kini belum ada ketentuan yang mengatur bahwa golongan pribumi tersebut termasuk di bawah pengurusan Balai Harta Peninggalan.

Pengertian Balai Harta Peninggalan berdasarkan rancangan undang-undang tentang Balai Harta Peninggalan adalah suatu unit Pelaksana Teknis dalam lingkungan Kementerian Hukum dan Hak Asasi Manusia selanjutnya membidangi perwalian, pengampuan, ketidakhadiran, harta peninggalan tidak terurus, pendaftaran surat wasiat, surat keterangan waris, kepailitan, aset bank dalam likuidasi, dan Harta Tidak Terurus. ${ }^{5}$

Berangkat dari hal tersebut, penulis menganggap bahwa permasalahan ini harus dianalisa lebih dalam untuk mengetahui bagaimana peran Balai Harta Peninggalan dalam peralihan Hak Waris Atas Tanah pada Warga Negara Indonesia Keturunan Arab di Daerah Istimewa Yogyakarta dan bagaimana akibat hukum apabila diketahui Surat Keterangan Waris keturunan Arab dikeluarkan oleh Pemerintah Desa atau Notaris terhadap peralihan Hak Atas Tanah.

\section{Rumusan Masalah}

Dalam tulisan ini dipaparkan dua pokok permasalahan, pertama, bagaimanakah peran Balai Harta Peninggalan dalam peralihan Hak Waris Atas Tanah pada Warga Negara Indonesia keturunan Arab di Daerah Istimewa

\footnotetext{
${ }^{5}$ Rancangan Undang-Undang tentang Balai Harta Peninggalan, Pasal 1 ayat (1).
} 
Yogyakarta? Kedua, apakah akibat hukum apabila diketahui Surat Keterangan Waris keturunan Arab dikeluarkan oleh Pemerintah Desa atau Notaris terhadap Peralihan Hak Atas Tanah?

\section{Tujuan Penelitian}

Penelitian ini bertujuan untuk: pertama, memahami Peran Balai Harta Peninggalan dalam Peralihan Hak Waris Atas Tanah pada Warga Negara Indonesia keturunan Arab di Daerah Istimewa Yogyakarta. Kedua, memahami akibat hukum apabila diketahui Surat Keterangan Waris keturunan Arab dikeluarkan oleh Pemerintah Desa atau Notaris terhadap Peralihan Hak Atas Tanah.

\section{Metode Penelitian}

Penelitian ini bersifat kualitatif, pemilihan informasi, bersifat purposive sampling, artinya penelitian tidak menentukan berapa jumlah informan yang akan diteliti, akan tetapi jumlahnya berkembang sesuai kebutuhan yang dirasakan peneliti di lapangan, setelah data sudah dianggap penuh, sehingga sudah mencukupi maka, tidak perlu menambah sampel yang baru. Tata cara ini diterapkan, apabila peneliti benar-benar ingin menjamin, bahwa unsur-unsur yang hendak ditelitinya masuk ke dalam sampel yang ditariknya. Untuk itu, maka dia menetapkan syarat-syarat tertentu yang harus dipenuhi, di dalam memilih unsurunsur dari sampel. Tata cara sampling ini, pernah juga dilakukan di dalam penelitian mengenai pengetahuan dan sikap kalangan hukum di Jakarta, terhadap hukum dan kependudukan'.

Data yang digunakan ialah data primer yang mana data penulis peroleh melalui penelitian di lapangan yang dilakukan dengan observasi dan wawancara maupun pengamatan langsung (observasi) di lokasi penelitian. Wawancara yakni tanya jawab yang dilakukan dengan seseorang untuk memperoleh informasi yang merupakan data primer dalam penelitian ini. Teknik wawancara yang dilakukan

\footnotetext{
${ }^{6}$ Soerjono Soekanto, Pengantar Penelitian Hukum, UI PRESS, Jakarta, 2008, hlm. 196.
} 
dalam penelitian ini dilakukan dengan cara tanya jawab langsung dengan pihakpihak yang menjadi subjek penelitian ini. Pedoman wawancara (interview guide) ${ }^{7}$ merupakan alat pengumpul data yang digunakan dalam penelitian ini.

Metode pendekatan undang-undang dilakukan dengan menelaah undangundang dan regulasi yang bersangkutan dengan isu yang ditangani. Pendekatan ini digunakan untuk mengkaji secara mendalam tentang Peranan Balai Harta Peninggalan dan Proses Hak Atas peralihan Waris keturunan Arab di Daerah Istimewa Yogyakarta. Pendekatan kasus dilakukan dengan cara melakukan telaah terhadap kasus-kasus yang berkaitan dengan isu yang dihadapi yang telah terjadi mengenai Peran Balai Harta Peninggalan dalam proses peralihan hak atas tanah berdasarkan Hak Waris bagi Keturunan Arab.

\section{Hasil Penelitian dan Pembahasan}

Peran Balai Harta Peninggalan dalam Peralihan Hak Waris Atas Tanah pada Warga Negara Indonesia Keturunan Arab di Daerah Istimewa Yogyakarta

Warga Negara Indonesia keturunan Arab di Yogyakarta saat ini semakin berkembang, dengan adanya perkumpulan warga keturunan Arab di Yogyakarta dengan nama perkumpulan Arjo (Arrohman Yogyakarta). ${ }^{8}$

Perkumpulan tersebut terbentuk sudah tiga tahun pada 2014 dengan anggota 80 kepala keluarga, namun yang aktif dalam paguyuban hanya 30 kepala keluarga. Kegiatan yang rutin dilaksanakan yaitu pengajian, bakti sosial dan mempunyai desa binaan yang berada di Muntilan.

Saat ini warga keturunan Arab di Yogyakarta tergolong eksis, hal ini dibuktikan dengan adanya perkumpulan yang menaungi golongan itu sendiri. Tidak dapat dipungkiri dari adanya perkumpulan itu maka banyaknya peralihan Hak Waris Atas Tanah pada golongan tersebut di pastikan banyak terjadi. Namun dari berbagai individu yang ada masih berbagai cara untuk memproses Turun Waris Hak Atas Tanah.

Proses turun waris hak atas tanah keturunan Arab diawali dengan alas hak yang disebut dengan Akta Keterangan waris, Akta keterangan waris itu sendiri

\footnotetext{
${ }^{7}$ Sartono Kartodirdjo, Metodologi Penelitian Masyarakat, Gramedia Pustaka Utama, Jakarta, 1983, hlm. 56.

8 Wawancara dengan Ketua Paguyuban Warga Keturunan Arab di Yogyakarta (Arjo) pada tanggal 30 Juli
} 2018. 
diperoleh dari suatu instansi negara yaitu Balai Harta Peninggalan. Untuk wilayah Yogyakarta proses mendapatkan Akta Keterangan Waris dapat diurus di kantor Balai Harta Peninggalan yang ada di Semarang Jawa Tengah.

Balai Harta Peninggalan Semarang terkait dalam proses Akta Keterangan Waris telah melakukan koordinasi dengan instansi terkait seperti Badan Pertanahan Nasional dan Pengadilan setempat. Balai Harta Peninggalan menginginkan apabila ada penetapan atau putusan mengenai turun waris keturunan Arab segera untuk koordinasi dengan pihak Balai Harta Peninggalan.

Balai Harta Peninggalan untuk dapat membuat Akta Keterangan waris hanya sebagai syarat wajib dari pemohon yang menginginkan adanya Akta Keterangan Waris tersebut, dalam artian bahwa yang berperan aktif untuk mendapatkan Akta Keterangan Waris yaitu pemohon dari Warga Keturunan Arab tersebut. Baik instansi yang membutuhkan Akta Keterangan Waris ataupun dari pemohon warga keturunan arab tersebut.

Format Akta Keterangan Waris yang dibuat oleh Balai Harta Peninggalan masing-masing wilayah mempunyai format masing-masing tidak ada acuan dalam format yang ditentukan, namun dalam pembagian waris tetap sama di mana pembagian waris tersebut merujuk pada pembagian waris Islam yang sudah di tentukan pembagiannya. ${ }^{9}$

Proses untuk mendapatkan Akta Keterangan Waris yang dikeluarkan oleh Balai Harta Peninggalan pemohon dapat langsung memohonkan sendiri Akta Keterangan Waris kepada Balai Harta Peninggalan namun dapat juga dikuasakan kepada orang lain dengan catatan harus dengan Surat Kuasa untuk proses Akta Keterangan dari yang bersangkutan kepada orang lain yang mengurusi Akta Keterangan Waris tersebut. Dalam kuasa tersebut harus jelas penggunaannya untuk apa kuasa itu dibuat dan ahli waris yang menguasakan harus semua menandatangani kuasa tersebut.

Biaya yang dikeluarkan oleh pemohon Akta Keterangan Waris harus sesuai dengan Peraturan Pemerintah Nomor 45 Tahun 2016 tentang Jenis Tarif

9 Wawancara dengan anggota teknis Hukum Balai Harta Peninggalan wilayah Semarang pada tanggal 12 September 2018 . 
Penerimaan Negara Bukan Pajak di lingkungan Kementerian Hukum dan Hak Asasi Manusia. Dalam peraturan tersebut sudah jelas mengenai biaya yang dikeluarkan oleh pemohon untuk memproses Surat Keterangan Waris.

Klasifikasi mengenai Warga Indonesia keturunan Arab untuk memproses Akta Keterangan Waris terkait Turun Waris Hak Tas Tanah pihak Balai Harta Peninggalan menyerahkan sepenuhnya kepada Instansi terkait yang mengurusi tanah yaitu Badan Pertanahan Nasional. Di mana klasifikasi tersebut kewenangan yang ada dalam Badan Pertanahan Nasional bagaimana WNI tersebut merupakan Keturanan Arab atau bukan. Dalam artian pihak Balai Harta Peninggalan hanya memproses apabila ada permohonan yang masuk.

Balai Harta Peninggalan juga terdapat koordinasi dengan Notaris di mana koordinasi tersebut yaitu dengan adanya laporan wasiat dan penyelesaian aset yang dikeluarkan oleh Balai Harta Peninggalan. Tidak serta merta pihak Notaris tidak adanya koordinasi terkait oleh Balai Harta Peninggalan terkait adanya wasiat yang ada.

Dalam hal Akta Keterangan Waris Warga Negara Indonesia Keturunan Arab merupakan mutlak produk dan kewenangan sepenuhnya yang dimiliki oleh Balai Harta Peninggalan. Maka apabila terdapat Akta Keterangan Waris Warga Negara Indonesia Keturunan Arab yang bukan melalui proses dari Balai Harta Peninggalan, akta tersebut dapat dinyatakan batal demi hukum karena tidak sesuai dengan aturan yang berlaku. Berdasarkan Pasal 20 ayat (1) Peraturan Pemerintah Nomor 10 Tahun 1961 tentang Pendaftaran Tanah, bahwa jika orang mempunyai hak atas tanah meninggal dunia, maka yang menerima tanah itu sebagai warisan wajib meminta pendaftaran peralihan tanah tersebut dalam waktu 6 bulan sejak tanggal meninggalnya orang itu. Selanjutnya dalam Pasal 23 ayat (1), untuk mendaftarkan peralihan hak karena warisan mengenai tanah yang telah dibukukan, maka kepada Kepala Kantor Pendaftaran tanah harus diserahkan Surat Keterangan Waris dari instansi yang berwenang. ${ }^{10}$

Balai Harta Peninggalan Semarang, dalam kedudukannya berdasarkan ketentuan pada ayat (1) Pasal 14 dari instruksi Voor de Governements Landmeters 35.

${ }^{10}$ Kementerian Hukum dan Hak Asasi Manusia, Buku Saku Tugas dan Fungsi Balai Harta Peninggalan, hlm. 
dalam Stbl. 1916 No. 517, jo Surat Menteri Dalam Negeri Cq. Kepala Direktorat Pendaftaran Tanah Direktorat Jenderal Agraria Departemen Dalam Negeri tanggal 20 Desember 1969 Nomor: DPT/12/63/12/69 jo. Peraturan Menteri Negara Agraria/Kepala Badan Pertanahan Nasional No. 3 Tahun 1997 tentang Ketentuan Pelaksanaan Peraturan Pemerintah No. 24 Tahun 1997 tentang Pendaftaran Tanah merupakan instansi yang berwenang menertibkan Surat Keterangan Hak Waris untuk Golongan Timur Asing (Arab). ${ }^{11}$

Dengan adanya ketentuan tersebut maka peralihan waris terhadap hak atas tanah dapat dinyatakan batal demi hokum, karena atas hak yang terdapat dalam ketentuan tersebut batal demi hukum. Balai Harta Peninggalan menghimbau baik semua instansi terkait untuk saling berkoordinasi mengenai Akta Keterangan Waris Warga Negara Indonesia Keturunan Arab, karena sangat penting dan masyarakat sendiri masih awam mengenai hal ini. Baik instansi terkait maupun masyarakat yang tergolong menjadi Warga Negara Indonesia Kerutunan Arab lebih memperhatikan ketentuan-ketentuan yang telah diatur agar ke depannya tidak terjadi masalah atau sengketa yang merugikan bagi semua pihak.

Balai Harta Peninggalan dalam hal ini selain mengurus harta kekayaan yang tak terurus juga mempunyai kewenangan yang mutlak untuk membuat Akta Keterangan Waris khususnya Akta Keterangan Waris Keturunan Arab. Balai harta peninggalan dalam kedudukannya berdasarkan ketentuan pada ayat (1) Pasal 14 dari Instruksi Voor de Gouvernements Landmeters dalam Stbl. 1916 No. 517, jo Surat Menteri Dalam Negeri Cq. Kepala direktorat Pendaftaran Tanah Direktorat Jenderal Agraria Departemen Dalam Negeri Tanggal 20 Desember 1969 Nomor: DPT/12/63/12/69 jo. Peraturan Menteri Negara Agraria/Kepala Badan Pertanahan Nasional No. 3 Tahun 1997 Tentang Pelaksanaan Peraturan Pemerintah No. 24 Tahun 1997 tentang Pendaftaran Tanah merupakan Instansi yang berwenang menerbitkan Surat Keterangan Hak Mewaris Untuk Golongan Timur Asing. ${ }^{12}$

${ }^{11}$ Ibid.

12 Ibid., hlm. 36. 


\section{Akibat Hukum Apabila Diketahui Surat Keterangan Waris Keturunan Arab Dikeluarkan oleh Pemerintah Desa atau Notaris terhadap Peralihan Hak Atas Tanah}

Peralihan hak atas tanah adalah berpindahnya hak atas tanah dari pemegang hak yang lama kepada pemegang hak yang baru. Ada 2 cara peralihan hak atas tanah, yaitu beralih dan dialihkan. Beralih menunjukkan berpindahnya hak atas tanah tanpa ada perbuatan hukum yang dilakukan oleh pemiliknya, misalnya melalui pewarisan. Sedangkan dialihkan menunjuk pada berpindahnya hak atas tanah melalui perbuatan hukum yang dilakukan pemiliknya, misalnya melalui jual beli. Levering adalah perbuatan hukum yang ditempuh guna memindahkan hak milik atas barang.

Levering merupakan salah satu cara untuk memperoleh hak milik karena adanya pemindahan hak milik dan seseorang yang berhak memindahkannya kepada orang lain yang berhak memperoleh hak milik. Cara memperoleh hak milik dengan levering merupakan cara yang paling banyak dilakukan dalam kehidupan masyarakat sekarang. Perkataan levering mempunyai dua arti yaitu: ${ }^{13}$ pertama, perbuatan yang berupa penyerahan kekuasaan belaka (feitelijke levering). Kedua, perbuatan hukum yang bertujuan memindahkan hak milik kepada orang lain (juridische levering).

Pewarisan adalah tindakan pemindahan hak milik atas benda dari seseorang yang telah meninggal dunia kepada orang lain yang ditunjuknya dan/atau ditunjuk pengadilan sebagai ahli waris. Menurut Pasal 20 PP No. 10 Tahun 1961, menyatakan bahwa jika orang yang mempunyai hak atas tanah meninggal dunia, maka yang menerima tanah itu sebagai warisan wajib meminta pendaftaran peralihan hak tersebut dalam waktu 6 bulan sejak meninggalnya orang itu. Setelah berlakunya PP No. 24 Tahun 1997, maka keterangan mengenai kewajiban mendaftarkan peralihan hak milik atas tanah karena pewarisan diatur dalam Pasal 36 PP No. 24 Tahun 1997.

Kematian seseorang menurut BW mengakibatkan peralihan segala hak dan kewajiban pada seketika itu juga. Hal ini dijelaskan dalam Pasal 833 BW yang berbunyi sebagai berikut: "sekalian ahli waris dengan sendirinya demi hukum

\footnotetext{
${ }^{13}$ Ridwan Syahrani, Seluk Beluk dan Asas-asas Hukum Perdata, Alumni, Bandung, 2004, hlm. 132.
} 
memperoleh hak atas segala barang, segala hak, dan segala piutang dari yang meninggal". Untuk membuktikan siapa-siapa yang berhak atas warisan yang ditinggalkan oleh seseorang yang telah meninggal (pewaris) dibutuhkan surat keterangan ahli waris, sebagai alat bukti yang menjadi dasar atas pembagian harta warisan, baik atas siapa yang berhak dan/atau berapa jumlah bagian yang berhak berdasarkan legitimate portie dan/atau berdasarkan wasiat. ${ }^{14}$

Dengan jatuhnya tanah kepada para ahli waris, terjadilah pemilikan bersama tanah hak milik jika tanah tersebut hanya satu-satunya. Akan tetapi, jika pewarisnya memiliki tanah tersebut sesuai dengan jumlah ahli waris dan telah dibuatkan surat wasiat, maka tanah dimaksud telah menjadi milik masing-masing ahli waris. Untuk memperoleh kekuatan pembuktian tanah dari hasil pewarisan, maka surat keterangan waris sangat diperlukan di samping sebagai dasar untuk pendaftaran tanahnya. ${ }^{15}$

Untuk melanjutkan kedudukan hukum bagi seseorang yang meninggal, sedapat mungkin disesuaikan dengan kehendak dari orang yang meninggal itu. Undang-undang berprinsip bahwa seseorang bebas menentukan kehendaknya tentang harta kekayaannya setalah ia meninggal dunia. Namun, bila orang dimaksud untuk menentukan sendiri ketika masih hidup tantang apa yang akan terjadi terhadap harta kekayaan, dalam hal demikian undang-undang kembali menentukan perihal peraturan harta yang ditinggalkan oleh seseorang yang dimaksud. ${ }^{16}$

Adanya penggolongan terhadap penduduk Indonesia sejak jaman belanda dahulu menyebabkan terjadinya pembedaan terhadap bentuk dan siapa pejabat yang berwenang untuk membuat surat keterangan waris, berdasarkan surat keputusan Departemen Dalam Negeri Direktorat Pendaftaran Tanah No. DPT/12/63/12/69 jo pasal 111 ayat 1 C point 4 PMNA Nomor 3 Tahun 1997.17

\footnotetext{
14 Raudatul Fitri, Prosedur Adminstrasi Pendaftaran Turun Waris Bagi Golongan Tionghoa Berdasarkan Peraturan Menteri Negara Agraria/Kepala Badan Pertanahan Nasional Nomor 3 Tahun 1997 Tentang Ketentuan Pelaksanaan Peraturan Pemerintah Nomor 24 Tahun 1997 Tentang Pendaftaran Tanah Di Kota Yogyakarta, (Tesis, Universitas Islam Indonesia, Yogyakarta) 2017, hlm. 108.

15 Adrian Sutedi, Peralihan Hak Atas Tanah Dan Pendaftarannya, Sinar Grafika, Jakarta, hlm. 102.

16 R. Subekti, Pokok-Pokok Hukum Perdata, Intermasa Indonesia, Jakarta, 1997, hlm. 85.

${ }^{17}$ Raudatul Fitri, Loc. Cit.
} 
Sejak berlakunya peraturan pemerintah Nomor 10 Tahun 1961 tentang pendaftaran tanah, sesuai Pasal 25, surat keterangan warisan itu merupakan suatu keharusan. Hanya saja pejabat yang berwenang untuk membuat keterangan waris itu belum ditentukan. ${ }^{18}$

Di BPN Kota Yogyakarta belum pernah ada laporan atau pengajuan peralihan Hak Atas Tanah WNI keturunan timur Asing khususnya keturunan Arab. Hal ini disampaikan langsung oleh Kepala Sub Seksi Pendaftaran Hak Atas Tanah. Berbeda jauh dengan peralihan hak atas tanah WNI keturunan Tionghoa di Kota Yogyakarta. Sering adanya laporan peralihan hak atas tanah WNI keturunan Tionghoa. ${ }^{19}$

BPN adalah sebagai instansi pencatat administrasi Peralihan Hak Atas Tanah, untuk melaku Peralihan Hak atas Tanah di Badan Pertanahan Nasional Yogyakarta, sebelum mendaftarkan Turun Waris, pemohon harus melengkapi beberapa syarat sebagai mana yang sudah ditentukan Badan Pertanahan Nasional, namun syarat utamanya adalah melampirkan surat keterangan waris. Bagi WNI keturunan Timur Asing termasuk keturunan Arab maka harus melampirkan surat keterangan waris dari Balai Harta Peninggalan di mana di dalam surat keterangan waris tersebut sudah terlampir pembagian hak waris. Selanjutnya BPN memeriksa berkas pengajuan yang diajukan pemohon serta memproses apabila persyaratan pengajuan di anggap telah memenuhi kualifikasi. ${ }^{20}$

Tidak adanya kualifikasi khusus yang ditetapkan Badan Pertanahan Nasional untuk WNI keturunan. Namun, untuk menghindari cacat administrasi atau kesalahan dalam permohonan peralihan hak waris atas tanah Badan Pertanahan Nasional terlebih dahulu melakukan verifikasi berkas yang dilakukan bagian analis pendaftaran hak atas tanah dan permohonan hak tanah. ${ }^{21}$

Akan lebih baik apabila pengurusan peralihan hak waris atas tanah tidak ada perbedaan antara WNI pribumi, keturunan Tionghoa dan timur asing. Hal ini akan

18 Adrian Sutedi, Op. Cit., hlm. 102.

19 Wawancara dengan Kepala seksi pendaftaran hak atas tanah Badan Pertanahan Nasional Yogyakarta pada tanggal 13 September 2018.

20 Wawancara dengan Kepala seksi pendaftaran hak atas tanah Badan Pertanahan Nasional Yogyakarta pada tanggal 13 September 2018.

21 Ibid. 
menjadi hal yang adil bagi semuanya dan bisa menguntungkan untuk semua pihak juga. Selain itu akan lebih baik jika adanya suatu instansi yang sama yang berwenang mengurus surat keterangan waris sebagai persyaratan utama sehingga adanya persamaan persyaratan antar semua pemohon baik pribumi ataupun Non pribumi.

Diketahui bahwa status kepemilikan hak atas tanah bagi WNI keturunan di Daerah Istimewa Yogyakarta turun satu derajat yaitu dari hak milik (HM) menjadi hak guna bangunan (HGB) hal tersebut tercantum dalam Surat Instruksi Wakil Gubernur DIY Nomor 898/I/A/1975 tentang Larangan Kepemilikan Hak atas Tanah bagi Warga Nonpribumi.

Instruksi Kepala Daerah Daerah Istimewa Yogyakarta Nomor K.898/I/A/1975 tentang Penyeragaman Policy Pemberian Hak atas Tanah Kepada Seorang WNI Non Pribumi atau yang disingkat Instruksi 1975, Instruksi Wagub DIY 1975, atau Instruksi 898/1975 adalah sebuah surat instruksi yang dibuat oleh Paku Alam VIII yang memerintahkan agar tidak memberikan milik tanah kepada warga negara non-pribumi meliputi "Europeanen" ("Eropa" kulit putih); "Vreemde Oosterlingen" ("Timur Asing") yang meliputi orang Tionghoa, Arab, India maupun non-Eropa lain di Daerah Istimewa Yogyakarta (DIY) dan hanya boleh diberikan hak guna.

Dalam hal pengajuan permohonan peralihan hak atas tanah WNI keturunan Timur Asing sama halnya dengan WNI pribumi dan WNI Keturunan Tionghoa. tidak adanya aturan khusus dari Badan Pertanahan Nasional Yogyakarta maupun Pusat. Tidak adanya ketentuan baku dalam pengajuan permohonan, namun Badan Pertanahan Nasional memberikan formatnya agar substansi dari isi permohonan peralihan tersebut didapat. Hal yang membedakan Persyaratan Permohonan Peralihan Hak atas tanah antara WNI keturunan timur asing, Tionghoa dan Pribumi adalah Surat Keterangan warisnya. ${ }^{22}$

22 Wawancara dengan Kepala seksi pendaftaran hak atas tanah Badan Pertanahan Nasional Yogyakarta pada tanggal 13 September 2018. 
Pembuatan surat keterangan waris berdasarkan penggolongan penduduk telah ada sejak jaman VOC, dewasa ini pada asas konkordansi Pasal 14 wet opde grootborken der nationale Schuld (Undang-Undang Tentang Bukum Besar Perutangan National Di Belanda), Pasal 14 ayat (2) Ordonnantie tanggal 22 Juli 1916, Staatsblad 1916; 517 diubah LN 1931: 168 dan LN 1937: 611, surat edaran departemen dalam negeri direktorat jendral Agraria tanggal 20 Desember 1969 No DPT/12/63/69., Fatwah Mahkamah Agung atas permintaan yang ditujukan kepada Ny, Sri Redjeki Kusnun, S.H., tertanggal Jakarta, 25 Maret 1991, No. KMA/041/III/1991 jo. Surat Ketua Mahkamah Agung Kepada Ketua Pengadilan tinggi, Pengadilan Tinggi Agama, Pengadilan Negeri, dan pengadilan agama seluruh Indonesia tertanggal Jakarta, 8 mei 1991 No. MA/Kumdil/171/v/k/1991., Pasal 111 ayat (1) huruf c angka 4 PP 24/1997 Tentang Pendaftaran Tanah, Pasal 42 ayat (1) jo. PERMENAG Agraria/Kepala BPN Nomor 3 Tahun 1997 tentang Ketentuan Pelaksanaan Peraturan Pemerintah Nomor 24b Tahun 1997.

Pembuatan surat keterangan waris oleh instansi yang berbeda-beda merupakan salah satu konsekuensi akibat masih berlakunya pluralisme sistem hukum waris dan ter dapatnya perbedaan kebutuhan keperdataan masing-masing "golongan penduduk". 23

Soedikno Mertokusumo menyatakan bahwa dalam pendaftaran Tanah dikenal 2 macam asas yaitu: pertama, Asas specialiteit. Artinya pelaksanaan pendaftaran tanah diselenggarakan atas dasar peraturan perundang-undangan tertentu, yang secara teknis menyangkut masalah pengukuran, pemetaaan dan pendaftaran peralihannya. Oleh karena itu, dalam pelaksanaan pendaftaran tanah dapat diberikan kepastian hukum terhadap hak atas tanah, yaitu memberikan data fisik yang jelas mengenai luas, letak dan batas-batas tanah. Kedua, Asas Openbaarheid (asas Publisitas). Asas ini memberikan data yuridis tentang siapa yang menjadi subjek haknya, apa nama hak atas tanah, serta bagaimana terjadinya peralihan dan pembebanannya. Data ini sifatnya terbuka untuk umum, artinya setiap orang dapat melihatnya.

${ }^{23}$ Herlin Budiono, Kumpulan Tulisan Hukum Perdata di Bidang Kenotariatan, Buku Kedua, Citra Aditya Bakti, Bandung, 2013, hlm. 88. 
Surat keterangan waris merupakan obligatoir yang lahir dari undang-undang, hal ini merupakan instrumen penting untuk melakukan peralihan hak suatu benda (lavering) dalam pengajuan permohonan peralihan hak atas di Badan Pertanahan Nasional. Terjadinya peralihan hak waris atas tanah karena adanya alas hak yaitu surat keterangan waris.

WNI keturunan timur asing atau Arab yang mana surat keterangan warisnya dikeluarkan oleh Balai Harta Peninggalan. Namun, dengan kondisi saat ini yang sangat jarang WNI keturunan timur asing membuat surat keterangan waris ke BHP khusufnya Kota Yogyakarta seperti yang disampaikan Badan Pertanahan Nasional Yogyakarta bahwa sampai saat ini belum adanya permohonan peralihan hak waris atas tanah WNI keturunan Timur Asing atau Arab tidak jauh dari kemungkinan adanya penyeludupan hukum atau mengelabui administrasi dengan cara mengakun pribumi dengan membuat surat keterangan waris di pemerintah desa atau Notaris.

Balai Harta Peninggalan selama ini hanya menunggu adanya pengajuan surat keterangan waris dari WNI keturunan. Hal ini bisa menjadi suatu celah untuk terjadinya penyeludupan hukum untuk tidak membuat Surat Keterangan Waris di BHP. 24

Ada dua akibat hukum apabila diketahui surat keterangan waris WNI keturunan Timur asing di buat oleh Notaris atau Pemerintahan Desa dalam Pengajuan Peralihan Hak Waris di Badan Pertanahan Nasional yaitu ;

\section{Batal Demi Hukum (Void Nietig)}

Bapak Sumardi, anggota teknis hukum Balai harta peninggalan Semarang. Mengatakan hal semacam itu batal demi hukum karena di anggap cacat secara administrasi dan tidak terpenuhinya syarat formil sebagaimana yang diwajibkan dalam undang-undang. Apabila Obligatoirnya tidak sah, maka otomatis laveringnya tidak sah atau batal demi hukum. Badan Pertanahan Nasional dapat

${ }^{24}$ Wawancara dengan anggota teknis Hukum Balai Harta Peninggalan wilayah Semarang pada tanggal 12 September 2018 . 
menolak langsung permohonan tersebut dan dinyatakan batal demi hukum dianggap permohonan tidak pernah ada. ${ }^{25}$

\section{Dapat Dibatalkan (Vernietigbaar)}

Apa bila permohonan peralihan hak waris sudah terjadi namun diketahui bahwa surat keterangan waris WNI keturunan Timur asing di buat oleh Notaris atau Pemerintahan Desa. Kepala seksi pendaftaran hak atas tanah Badan Pertanahan Nasional Yogyakarta mengatakan hal dapat di lakukan pembatalan dengan mengajukan gugatan pengadilan. Karena adanya cacat kehendak, yaitu salah satu pihak tidak memenuhi kehendak yang dianggap telah disepakati dengan menyerahkan SKW yang dibuat oleh Balai Harta Peninggalan sebagai mana d idalam peraturan. Namun, Pihak BPN akan berkoordinasi dan melakukan pendekatan serta pemanggilan kepada pemohon untuk melakukan pengajuan ulang dengan memenuhi persyaratan yang sesuai peraturan. ${ }^{26}$

\section{Penutup}

Proses turun waris hak atas tanah keturunan Arab wajib menyertakan dengan alas hak yang disebut dengan Akta Keterangan Waris. Akta Keterangan Waris tersebut diperoleh dari Balai Harta Peninggalan. Balai Harta Peninggalan mempunyai tugas dan kewenangan mengenai pembuatan Akta Keterangan Hak Waris (verklaring van erfrecht) Bangsa Timur Asing, kecuali Tionghoa, ditentukan pada ayat (1) dalam Pasal 14 dari Instruksi voor de Gouvernements Landmeters dalam Stb. 1916 No. 517. Untuk wilayah Yogyakarta proses mendapatkan Akta Keterangan Waris dapat diurus di Kantor Balai Harta Peninggalan yang ada di Semarang Jawa Tengah. Tanpa disertakan alas hak tersebut maka peralihan hak turun waris keturunan Arab dapat dinyatakan batal demi hukum.

Akta Keterangan Waris Warga Negara Indonesia Keturunan Arab merupakan mutlak produk dan kewenangan sepenuhnya yang dimiliki oleh Balai Harta Peninggalan. Maka apabila terdapat Akta Keterangan Waris Warga Negara Indonesia Keturunan Arab yang bukan melalui proses dari Balai Harta

25 Ibid.

26 Wawancara dengan Kepala seksi pendaftaran hak atas tanah Badan Pertanahan Nasional Yogyakarta pada tanggal 13 September 2018. 
Peninggalan, akta tersebut dapat dibatalkan demi hukum karena tidak sesuai dengan aturan yang berlaku. Berdasarkan Pasal 20 ayat (1) Peraturan Pemerintah Nomor 10 Tahun 1961 tentang Pendaftaran Tanah, bahwa jika orang mempunyai hak atas tanah meninggal dunia, maka yang menerima tanah itu sebagai warisan wajib meminta pendaftaran peralihan tanah tersebut dalam waktu 6 bulan sejak tanggal meninggalnya orang itu. Selanjutnya dalam Pasal 23 ayat (1), untuk mendaftarkan peralihan hak karena warisan mengenai tanah yang telah dibukukan, maka kepada Kepala Kantor Pendaftaran tanah harus diserahkan Surat Keterangan Waris dari instansi yang berwenang. Dalam kewenangan peralihan waris keturunan Arab tersebut alas hak yang berwenang untuk mengeluarkan Akta Keterangan Waris yaitu Balai Harta Peninggalan. Surat keterangan waris merupakan obligatoir yang lahir dari undang-undang, hal ini merupakan instrumen penting untuk melakukan peralihan hak suatu benda (lavering) dalam pengajuan permohonan peralihan hak atas di Badan Pertanahan Nasional. Ada dua akibat hukum apabila diketahui surat keterangan waris WNI keturunan Timur asing di buat oleh Notaris atau Pemerintahan Desa dalam Pengajuan Peralihan Hak Waris di Badan Pertanahan Nasional yaitu Batal demi hukum apabila sebelum dilakukan permohonan dan dapat di batalkan apabila setelah terjadinya peralihan.

\section{Daftar Pustaka}

\section{Buku}

Adjie, Habib, Pembuktian Sebagai Ahli Waris Dengan Akta Notaris (Dalam Bentuk Akta Keterangan Waris), Mandar Maju, Bandung, 2008.

Budiono, Herlin, Kumpulan Tulisan Hukum Perdata di Bidang Kenotariatan, Buku Kedua, Citra Aditya Bakti, Bandung, 2013.

Kementrian Hukum dan Hak Asasi Manusia, Buku Saku Tugas dan Fungsi Balai Harta Peninggalan.

Oemarsalim, Dasar-Dasar Hukum Waris di Indonesia, Rineka Cipta, Jakarta, 2006.

Soekanto, Soerjono, Pengantar Penelitian Hukum, UI PRESS, Jakarta, 2008.

Subekti, R., Pokok-Pokok Hukum Perdata, Intermasa Indonesia, Jakarta, 1997.

Sutedi, Ardian, Peralihan Hak Atas Tanah dan Pendaftaranya, Sinar Grafika, Jakarta, 2010. 
Syahrani, Ridwan, Seluk Beluk dan Asas-asa Hukum Perdata. Alumni, Bandung, 2004.

Zamzami, Mukhtar, Perempuan \& Keadilan dalam Hukum Kewarisan Indonesia, Prenada Media Group, Jakarta, 2013.

\section{Peraturan Perundang-Undangan}

Peraturan Menteri Negara Agraria/Kepala Badan Pertanahan Nasional Nomor 3 Tahun 1997 tentang Pelaksanaan Peraturan Pemerintah Nomor 24 Tahun 1997 tentang Pendaftaran Tanah.

Surat Departemen Dalam Negeri Direktorat Jendral Agraria Direktorat Pendaftaran Tanah Nomor Dpt/12/63/12/96 tentang Surat Keterangan Waris dan Pembuktian Kewarganegaran. 